\title{
Submarine groundwater discharge to the Baltic coastal zone: Impacts on the meiofaunal community
}

\author{
L. Kotwicki ${ }^{\text {a,* }}$, K. Grzelak ${ }^{\text {a }}$, M. Czub ${ }^{\text {b }}$, O. Dellwig ${ }^{\text {c }}$, T. Gentz ${ }^{\text {d, B. Szymczycha }}{ }^{\text {a }}$, M.E. Böttcher ${ }^{\mathrm{c}}$ \\ a Institute of Oceanology Polish Academy of Sciences, Sopot, Poland \\ b University of Gdansk, Poland \\ c Leibniz Institute for Baltic Sea Research, Warnemünde, Germany \\ d Alfred Wegener Institute for Polar and Marine Research, Bremerhaven, Germany
}

\section{A R T I C L E I N F O}

\section{Article history:}

Received 16 December 2011

Received in revised form 14 June 2013

Accepted 18 June 2013

Available online $\mathrm{xxxx}$

\section{Keywords:}

Submarine groundwater discharge (SGD)

Ecological impact

Meiobenthos

Permeable sediments

Coastal zone

\begin{abstract}
A B S T R A C T
The discharge of groundwater into the sea affects surrounding environments by changing the salinity, temperature and nutrient regimes. This work reports the spatial effects of a submarine groundwater discharge (SGD) on the abundance and structure of the meiofaunal community in the shallow area of Puck Bay (Baltic Sea). Several field expeditions in the years 2009 and 2010 found that low-saline groundwater escapes into the bay from permeable, sandy, near-shore sediments. The SGD literature has grown rapidly during the current decade; however, the effects of this type of disturbance on the shallow sandy bottom fauna have thus far been little studied. We provide evidence that the discharge of groundwater has a clear effect on meiofaunal assemblages in the research area. This effect was reflected in a significant decline of certain meiofaunal taxa, mainly nematodes and harpacticoids, as well as in altered patterns of temporal distribution and small-scale (vertical) zonation of meiofaunal assemblages. Overlooking submarine groundwater discharge processes may lead to serious misinterpretations of ecological data. It is clear that groundwater discharge phenomena should be considered in future scientific studies.
\end{abstract}

(C) 2013 Elsevier B.V. All rights reserved.

\section{Introduction}

Submarine groundwater discharge (SGD) and the associated chemical loading of coastal waters have recently become a widely recognised phenomenon (Moore, 2010 and references within). Moore (2010) defines SGD as an exchange of water between land and sea that occurs in coastal aquifers where biogeochemical reactions modify the water chemistry. Many studies have indicated that SGD is important because it transports chemical fluxes from the land to the coastal ocean, at times in quantities that exceed the magnitude of river-borne fluxes (Burnett et al., 2003; Kim et al., 2005). In some areas, SGD can have greater ecological consequences than surface runoff (Costa et al., 2006). Thus, overlooking the groundwater discharge in a coastal water budget (in terms of freshwater input and associated chemical constituents) could lead to a misinterpretation of ecological data in a wide range of studies, such as those concerning the eutrophication of coastal waters, coastal pollution, or the flux of dissolved components between the sea floor and the water column.

Externally added nutrients are known to increase primary production and eutrophication, to change the species composition and to

\footnotetext{
* Corresponding author at: Marine Ecology Department, Institute of Oceanology Polish Academy of Sciences (IO PAN), Powstancow Warszawy 55, 81-712 Sopot, Poland. Tel.: + 48587311783 .

E-mail address: lechk@iopan.gda.pl (L. Kotwicki).
}

alter the cycles of energy flow between the pelagic and benthic zones (Gazeau et al., 2004; Nixon et al., 1986; Opaliński et al., 2010; Valiela et al., 1990). The nutrients, organic compounds and metals transported by SGD through coastal aquifers are key factors in initiating phytoplankton blooms (Lapointe et al., 1990) and serve as important sources of iron (Windom et al., 2006) and phosphate in the surrounding waters (Corbett et al., 2002). Consequently, SGD may directly impact both near-shore benthic and pelagic biotas (Burnett et al., 2006; Moore, 1999; Pempkowiak et al., 2010). However, reports on the influence of SGD on marine organisms are rather scarce. Kohout (1964) showed a relationship between groundwater discharge and the biological zonation of Biscayne Bay, Florida. Bussmann et al. (1999) investigated the importance of bacterial activity in a discharge area, and Miller and Ullman (2004) described the alteration of local benthic habitats near a discharge point. Most studies to date have focused on the quantitative and qualitative characterisation of SGD, its influence on the coastal nutrient budget, and the methodological approaches of SGD quantification (e.g., Beck et al., 2008; Jeong et al., 2012; Rapaglia et al., 2012).

In spite of the increasing interest in and knowledge and acceptance of the relevance of SGD to coastal zones, relatively little is known about SGD for the Baltic Sea. Until now, geochemical SGD studies have been conducted in only three areas of the Baltic: the Gulf of Finland, the Eckernförde Bay (Germany) and the Gulf of Gdansk (Poland). In the Polish coastal zone, the first observation was made in the early 1990s in Puck Bay. Direct measurements in 
the Gulf of Gdansk showed an unusual vertical distribution of temperature and salinity in the water column as well as additional hydrochemical effects due to submarine groundwater seepage (Falkowska, 1998; Falkowska and Piekarek-Jankowska, 1999; Falkowska et al., 1998; Jankowska et al., 1994; Piekarek-Jankowska, 1994, 1996). Such supplies of freshwater and nutrients via groundwater seepage may lead to ecological problems such as the steady deterioration of water quality or changes to the structural and functional features of benthic assemblages.

We report here on the impacts of groundwater discharge on the infaunal structure in the shallow area of Puck Bay in the southern Baltic Sea. To our knowledge, no previous observations have been reported for the Baltic Sea. We focused on small metazoan organisms collectively known as meiofauna. Permeable shallow water sediments provide habitats for diverse meiofaunal communities. In some cases, these communities may even exceed macrofauna in biomass and make a greater contribution to carbon processing by benthic communities (McLachlan and Brown, 2006; Schratzberger and Jennings, 2002). Moreover, due to their small size, short life cycles and lack of planktonic stages, meiofauna are useful in assessing environmental disturbances (Austen et al., 1994; Schratzberger and Warwick, 1999). The state of meiofaunal assemblages can be considered a reflection of the overall health of a marine habitat, especially for detecting early responses to environmental changes (Kennedy and Jacoby, 1999).

The objectives of this study were to establish the influence of SGD on the existing faunal community in the Polish coastal zone of the Baltic Sea and to identify the potential threats of SGD to the biota. We hypothesised that groundwater discharge can modify habitat complexity and cause significant differences in the meiofaunal assemblages at discharge locations compared to reference locations.

\section{Materials and methods}

\subsection{Study area}

An SGD area was observed in the shallow littoral zone of Puck Bay (southern Baltic Sea). This part of the Gulf of Gdansk is well known for its high eutrophication rates due to anthropogenic impacts (Lysiak-Pastuszak, 2000). Puck Bay is separated from the open waters of the Baltic by the narrow, 36-km Hel Peninsula (Fig. 1). Hel Spit evolved during the Holocene, and its coast basically consists of recent alluvial and littoral zone Holocene sediments of 10 to $100 \mathrm{~m}$ in depth (Schoeneich, 1965).

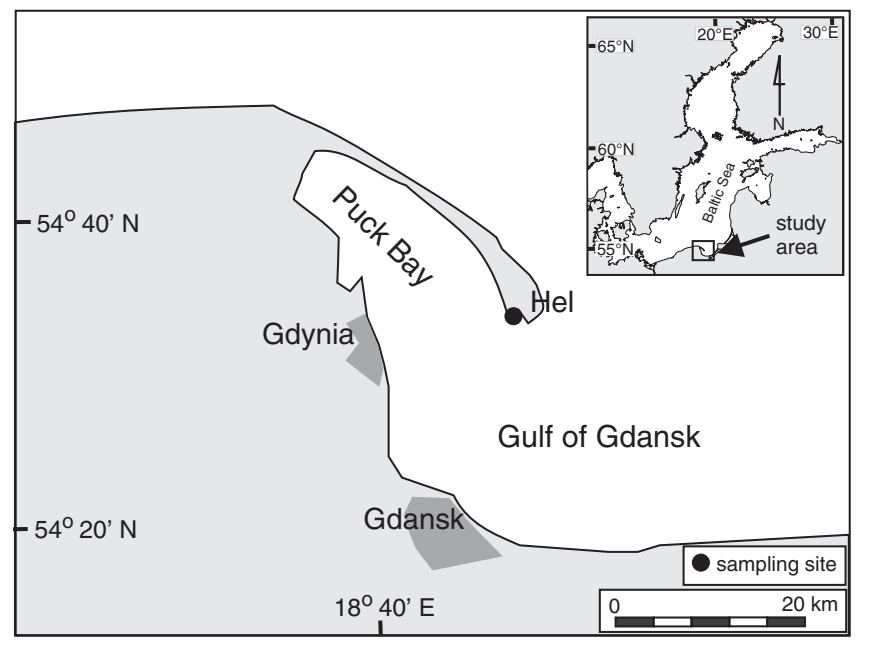

Fig. 1. Localisation of the sampling groundwater seepage area in Puck Bay (the Baltic Sea).

\subsection{Sampling strategy}

Research was conducted in the shallow area (0.5-1.5 $\mathrm{m}$ depth) along the municipal beach of the city of Hel $\left(54^{\circ} 36^{\prime} 25^{\prime \prime} \mathrm{N}, 18^{\circ} 47^{\prime} 57^{\prime \prime} \mathrm{E}\right)$ from March 2009 to October 2010 during six field investigations in different seasons. Material was collected from two sites: an "impacted" site (with groundwater discharge) and a "non-impacted" site (without groundwater discharge). An area with near-shore seepage close to the beach line was initially identified by simply observing gas bubbles escaping from the permeable sediment into the water column. Further investigation (described below) involved the application of pore-water lances to measure the SGD composition, which we extrapolated on the basis of vertical comparisons of the geochemical parameters with salinity.

Methane concentrations in the pore waters and bottom water samples were analysed by gas chromatography (Kampbell et al., 1989) using a Thermo Finnigan (Waltham, USA) TraceGC equipped with a flame-ionisation detector and a Porapak Q column.

In situ measurements of the methane flux from the sediment into the water column were performed with an underwater mass spectrometer (Bell et al., 2007, 2011; Gentz and Schlüter, 2012; Schlüter and Gentz, 2008; Short et al., 2001, 2006; Wenner et al., 2004). Fluxes were calculated on the basis of changes in gas concentrations within the chamber over time.

Following ex situ and in situ chemical identification, near-shore SGD flow rates were estimated using Lee-type seepage meters (Lee, 1977). A simple set of 3 to 5 benthic chambers $\left(0.25 \mathrm{~m}^{2}\right)$ with a plastic bag attached to a collector atop each seepage meter was used to collect groundwater. Plastic bags were removed after previously established time intervals, and the volume changes in the bags were used to estimate discharge fluxes.

Sediment samples from both the impacted and non-impacted sites were collected during each field investigation as follows:

- 6 replicates for meiofauna analyses (3.6- $\mathrm{cm}$ diameter Plexiglas's core) in 4 layers $(0-5,5-10,10-15$ and $15-20 \mathrm{~cm})$; identification of major groups (higher taxa)

- 1 replicate for sediment analysis (3.6- $\mathrm{cm}$ diameter Plexiglas's core) in 4 layers $(0-5,5-10,10-15$ and $15-20 \mathrm{~cm})$; grain-size analysis

- 3 replicates for permeability measurements.

Meiofauna - benthic organisms that pass through a $0.5-\mathrm{mm}$ sieve but are retained by a 0.032-mm mesh (Giere, 2009) - were sampled with Plexiglas's cores $3.6 \mathrm{~cm}$ in diameter and $30 \mathrm{~cm}$ in length and equipped with rubber stoppers. Cores were pushed at least $20 \mathrm{~cm}$ into the sediment. After applying the upper stopper, the core was gently removed from the sediment, and the lower stopper was emplaced. The cores were transported vertically to the surface and placed in a stand. 6 replicates were collected from each site, except in March 2009, when only 3 replicates were taken. After the field work, the sediment samples were immediately transported to the laboratory, where they were sliced into 4 consecutive layers at depths of $0-5,5-10,10-15$, and $15-20 \mathrm{~cm}$. They were then preserved in a $4 \%$ formaldehyde solution with Bengal Rose stain. To extract the meiofaunal organisms from the sediments, we used a standard method of decantation (Pfannkuche and Thiel, 1988). The abundance of each identified taxon is given for the $10 \mathrm{~cm}^{2}$ area of a given sediment thickness.

To determine the grain-size distribution, sediment samples were taken around the meiofaunal samples, divided according to the same method used for the meiofauna, dried for $24 \mathrm{~h}$ at $60{ }^{\circ} \mathrm{C}$, and sieved through thirteen 0.5 -phi intervals. The grain-size statistics (mean, sorting, skewness, and kurtosis) were calculated using Gradistat software (Blott and Pye, 2001), and the sediments were classified according to the method of Folk and Ward (1957).

To measure the permeability of the sediment, undisturbed sediment cores were placed on the permeameter, and 3 replicate cores 


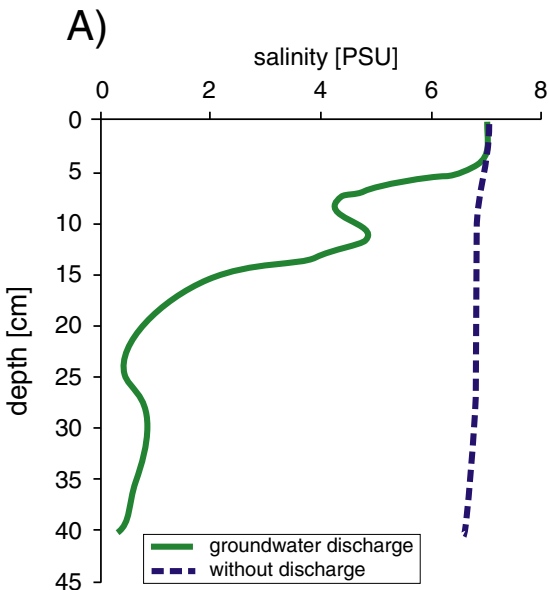

B)

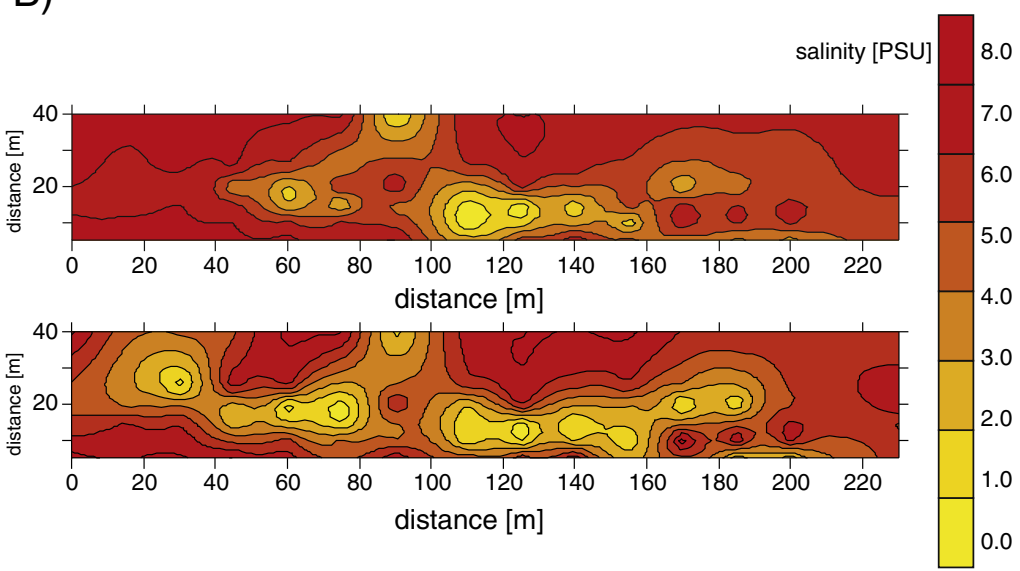

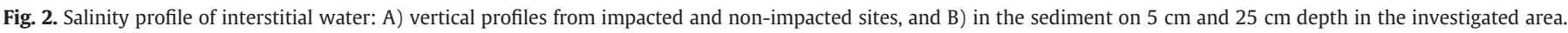

were selected for permeability measurements, $k\left[\mathrm{~cm}^{2}\right]$, by using the standard head method described by Klute and Dirksen (1986).

\subsection{Statistical analyses}

Differences in the meiofaunal assemblage from the impacted and non-impacted sites among the different seasons and sediment layers were tested by means of non-parametric permutational ANOVA (PERMANOVA). The data set was analysed using a 4-factor mixed model design (factors: Site (Si; fixed); Season (Se; fixed); Cores (Co; random and nested in SixSe); and Sediment layers (La; fixed)). The data were square-root transformed prior to analysis, and the Bray-Curtis similarity index was used to calculate resemblance. A non-metrical multi-dimensional scaling plot (MDS) was used to visualise the PERMANOVA results and to illustrate the interaction terms. A two-way crossed ( $\mathrm{Si}, \mathrm{Se}$ ) univariate PERMANOVA test was performed on the mean total density data (by summing up layers and averaging over cores). Separate two-way crossed (Si, Se) PERMANOVA tests were performed to analyse the mean grain-size and permeability data. The Euclidean distance on log-transformed data served as the resemblance matrix.

A DISTLM (distance-based linear model) was used to interpret the major patterns of variation in the meiofaunal data and to analyse the relationship between the meiofaunal communities and environmental variables. The following available environmental data were used: mean grain size, sorting, skewness, kurtosis, salinity, and the concentrations of dissolved inorganic carbon (DIC), dissolved organic carbon (DOC), nitrate $\left(\mathrm{NO}_{3}\right)$, nitrite $\left(\mathrm{NO}_{2}\right)$, ammonium $\left(\mathrm{NH}_{4}\right)$ and orthophosphate $\left(\mathrm{PO}_{4}\right)$

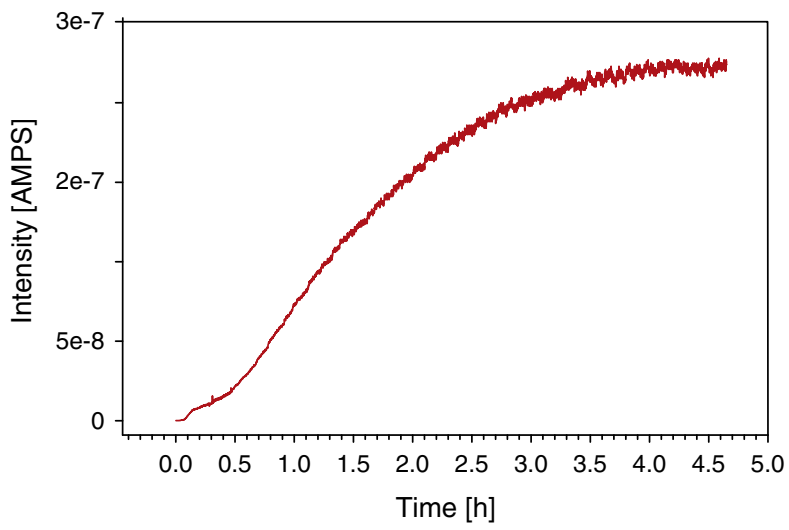

Fig. 3. Estimated methane flux on the impacted site in the shallow area of Puck Bay. in the groundwater samples. Detailed descriptions of the nutrients and carbon concentrations can be found in Szymczycha et al. (2012). The assemblage DISTLM was constructed using a step-wise selection procedure and the adjusted $\mathrm{R}^{2}$ as the selection criterion for fitting the best explanatory environmental variables in the model. All the analyses were performed using the PRIMER v6 with PERMANOVA + add-on software package (Anderson et al., 2008).

\section{Results}

Gas bubbles later identified as methane were first observed seeping from the sediment into the water column from the shallow coastal zone at a depth of 0.5 to $1.5 \mathrm{~m}$, close to the beach line in the Hel region during a 2004 field study for the COSA (COastal SAnds as biocatalytical filters) project under the 5th EU Framework programme. During field work under the AMBER project (BONUS +) in 2009 and 2010, researchers found low-salinity groundwater escaping into Puck Bay through seeps within the permeable near-shore sandy sediments of the Hel Peninsula coast (Fig. 2a, b). Salinity varied within the research site and decreased to 0.1 PSU in the shallow pore waters (the distribution in May 2010 is given as an example). A map of the data from pore-water lances allowed us to define the main seepage area and the salinity gradients caused by the advective mixing of brackish waters with upwardly migrating fresh groundwater. At the impacted site with groundwater seepage, the salinity clearly decreased with depth from 7 to 0.1 PSU, whereas at the site without seepage, only a slight decrease of salinity in the deeper sediment layers was noted (Fig. 2a).

Timed deployment of the benthic seepage-meters allowed us to estimate seepage rates up to $187 \mathrm{l} \mathrm{m}^{-2} \mathrm{~d}^{-1}$, but the data varied significantly with the season, averaging $10-40 \mathrm{l} \mathrm{m}^{-2} \mathrm{~d}^{-1}$ in winter/ spring and $50-1501 \mathrm{~m}^{-2} \mathrm{~d}^{-1}$ in summer/autumn. The total average value of the estimated direct inflow of groundwater for the entire research area is approximately $120 \mathrm{~m}^{3} \mathrm{~d}^{-1}$.

The substrate was medium sand, well or moderately well sorted, mostly symmetrical, and platy- or mesokurtic for all investigated months in 2009 and 2010. The mean grain size differed among the sampling sites (Table 1, PERMANOVA: $\mathrm{F}=6.33, \mathrm{p}=0.019$ ) and the seasons $(F=5.15, p=0.002)$, with higher values at the impacted site. At the impacted site, the sediment was coarser at every depth layer and varied from $347 \mu \mathrm{m}$ in the surface layer to $408 \mu \mathrm{m}$ in the deepest layer (average of 2009/2010 data), compared to $334 \mu \mathrm{m}$ and $360 \mu \mathrm{m}$, respectively, at the site without seepage. A similar pattern of increasing grain size with depth was noted at both sites. The average measured permeability values varied greatly, ranging 
Table 1

Mean grain size values $[\mu \mathrm{m}]$ for particular depth layers at the investigated sites in different seasons (impacted: with groundwater seepage, non-impacted: without groundwater seepage).

\begin{tabular}{|c|c|c|c|c|c|c|c|c|}
\hline & & \multirow[b]{3}{*}{ Layer } & \multicolumn{3}{|l|}{2009} & \multicolumn{3}{|l|}{2010} \\
\hline & & & March & September & November & March & May & October \\
\hline & & & \multicolumn{6}{|c|}{ Mean grain size $[\mu \mathrm{m}]$} \\
\hline \multirow[t]{10}{*}{ Sediment depth layer } & \multirow[t]{5}{*}{ Impacted } & $0-5 \mathrm{~cm}$ & 267.7 & 262.7 & 286.0 & 379.3 & 472.8 & 413.8 \\
\hline & & $5-10 \mathrm{~cm}$ & 281.5 & 359.0 & 331.6 & 340.5 & 485.8 & 358.3 \\
\hline & & $10-15 \mathrm{~cm}$ & 435.7 & 463.3 & 354.0 & 393.7 & 411.7 & 377.4 \\
\hline & & $15-20 \mathrm{~cm}$ & 409.1 & 469.4 & 373.0 & 411.8 & 437.8 & 347.1 \\
\hline & & $0-20 \mathrm{~cm}$ & 348.5 & 388.6 & 336.1 & 381.3 & 452.0 & 374.1 \\
\hline & \multirow[t]{5}{*}{ Non impacted } & $0-5 \mathrm{~cm}$ & 271.1 & 297.9 & 285.4 & 394.5 & 404.8 & 351.9 \\
\hline & & $5-10 \mathrm{~cm}$ & 266.5 & 307.9 & 325.1 & 398.4 & 380.0 & 309.4 \\
\hline & & $10-15 \mathrm{~cm}$ & 351.1 & 326.5 & 349.7 & 414.8 & 402.5 & 281.4 \\
\hline & & $15-20 \mathrm{~cm}$ & 395.0 & 323.7 & 340.9 & 430.2 & 409.4 & 265.9 \\
\hline & & $0-20 \mathrm{~cm}$ & 320.9 & 314.0 & 325.3 & 409.5 & 399.2 & 302.1 \\
\hline
\end{tabular}

between $1.95 * 10^{-11}$ in September 2009 and $5.55 * 10^{-11} \mathrm{~m}^{2}$ in May 2010 (Table 2). The PERMANOVA test showed statistically significant differences between the sites and seasons ( $F=162.9$, $\mathrm{p}=0.001$ and $\mathrm{F}=855.8, \mathrm{p}=0.001$, respectively). The seasonal effect was markedly different at the two sites. The permeability values exhibited two phases: (1) lower, more stable values in the first year and (2) higher, more variable values in the second year. Permeability was significantly higher at the impacted site except in November 2009, the only month when the differences between the sites were not significant (pair-wise PERMANOVA test, $\mathrm{p}>0.05$ ).

The average methane concentration in the water and pore water in the research area varied significantly depending on the sampling site. This variability was correlated with methane emissions from the sediment to the water column. The interstitial water was characterised by a very high methane concentration (mean values $700 \mu \mathrm{mol} / \mathrm{l}$ ) at the sites with groundwater seepage and where the salinity decreased to 0.5 PSU. Maximum methane concentrations, up to $3413 \mu \mathrm{mol} / \mathrm{l}$ in the pore water at a sediment depth of $20 \mathrm{~cm}$, were noted in February 2010. Estimated values of methane flux at the impacted site reached $974 \mathrm{mmol} \mathrm{m}^{-2} \mathrm{~d}^{-1}$ (Fig. 3).

The highest total meiofaunal densities, integrated over the upper $20 \mathrm{~cm}$ of the sediment, were recorded at the non-impacted site, with a maximum average abundance of $1748 \mathrm{ind} / 10 \mathrm{~cm}^{2}$ in November 2009 and a minimum abundance of $111 \mathrm{ind} / 10 \mathrm{~cm}^{2}$ in March 2010. In contrast, the highest meiofaunal densities at the impacted site $\left(751\right.$ ind $\left./ 10 \mathrm{~cm}^{2}\right)$ were noted in September 2009, and the lowest were noted in March 2010 ( 82 ind $/ 10 \mathrm{~cm}^{2}$ ). Generally, total meiofaunal densities differed significantly between the impacted and non-impacted sites in most seasons (Fig. 4). The only time that no significant differences were observed was March of 2009 and 2010 (PERMANOVA pair-wise test, $\mathrm{p}>0.05$ ). A total of 14 higher taxa (two represented by larval stage Copepoda nauplii and Cirripedia nauplii) were recorded at the two study sites, and all taxa were noted at both sites. Between 7 and 11 taxa were recorded at the sampling site, with no significant differences in the number of meiofaunal taxa between the impacted and non-impacted sites (Table 3). 5 taxa were always present in the analysed samples: Nematoda, Harpacticoida, Gastrotricha, Oligochaeta and nauplii of Copepoda. Other taxa occurred only occasionally, such as Polychaeta and Tardigrada, or in low numbers, such as Acari and Bivalvia.

Nematodes dominated both sites in all sampling seasons and, together with the three other taxa, constituted up to $90 \%$ of the total meiofaunal density. At the impacted site, rotifers, turbellarians and harpacticoids followed nematodes in abundance; at the non-impacted site, the occurrence of turbellarians was lower, and these were replaced by increased number of gastrotrichs. Moreover, the percentage of nematodes was higher in the non-impacted site than in the impacted site (66.2\% and $57.4 \%$, respectively). A similar pattern was observed for Harpacticoida (6.5\% and 3.5\%, respectively). Large differences in nematode densities were observed between the investigated sites (Table 3). The density of these taxa at the impacted site ranged between 68 ind $/ 10 \mathrm{~cm}^{2}$ (March 2010) and 160 ind $/ 10 \mathrm{~cm}^{2}$ (September 2009). Densities were considerably higher at the non-impacted site, with values between 81 ind $/ 10 \mathrm{~cm}^{2}$ (March 2010) and 1471 ind $/ 10 \mathrm{~cm}^{2}$ (November 2009). In comparison to the impacted site, the non-impacted site also had considerably higher densities of Harpacticoida. The highest recorded density at the non-impacted site $\left(107 \mathrm{ind} / 10 \mathrm{~cm}^{2}\right)$ was five-fold greater than at the impacted site $\left(21 \mathrm{ind} / 10 \mathrm{~cm}^{2}\right)$.

The PERMANOVA community results showed significant differences between all investigated factors and their interactions $(p<0.01$; Table 4). A large site effect as well as large layer and seasonal effects can be seen (Table 3; Fig. 5). However, the size of the sediment-layer effect varies among the investigated sites. More specifically, at the non-impacted site, the points indicating sediment layers change gradually (along the first MDS axis), while at the impacted site, the difference between the surface layer (layer 1) and the other layers is much greater (Fig. 5). The studied sites harbour distinct meiofaunal assemblages, which are indicated by a clear separation of samples visible in Fig. 6a. The observed differences are mainly associated with the presence of nematodes and harpacticoids (Fig. 6b, c) and their gradually increasing abundance. Moreover, a clear separation of the meiofaunal assemblage from September 2009 can be seen, which is because of the very high

Table 2

Mean permeability of the sediment at the investigated sites in different seasons (impacted: with groundwater seepage, non-impacted: without groundwater seepage).

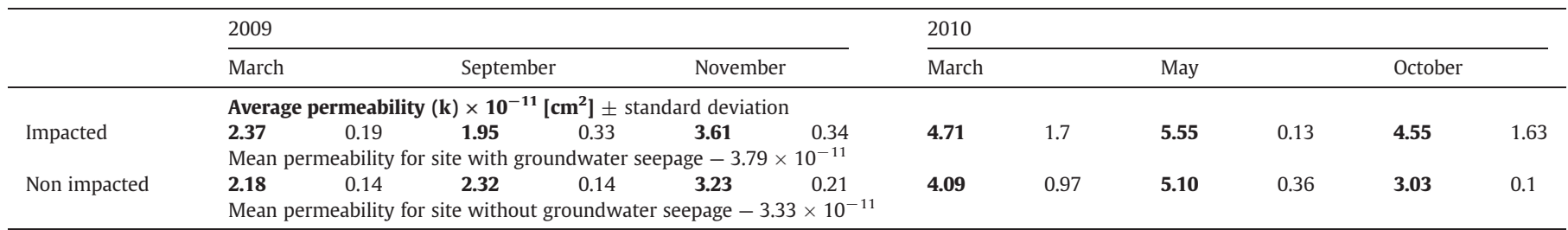




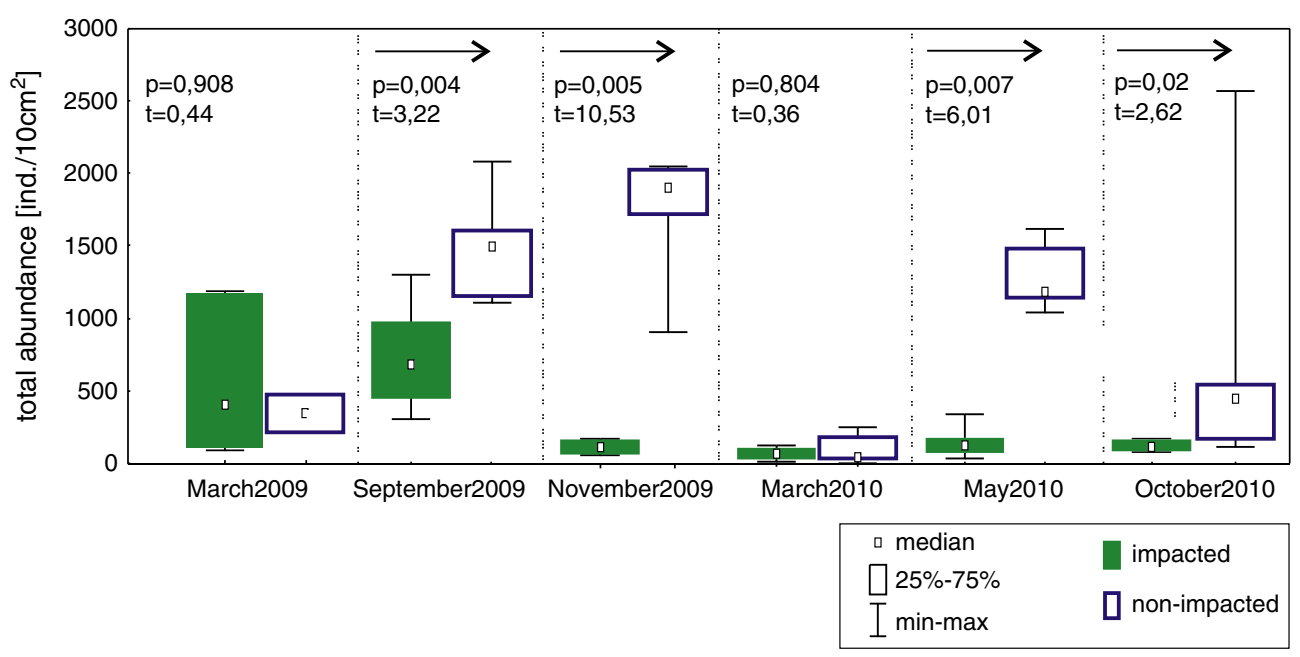

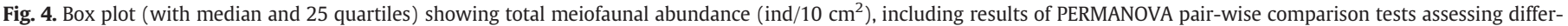
ences in meiofaunal densities between impacted and non-impacted sites during investigated seasons.

densities of Turbellaria and Rotifera that were not observed in other seasons.

The total meiofauna abundance consistently decreased with increasing sediment depth (Fig. 7). A general pattern can be observed despite the season and site: the highest densities were always found in the upper $5 \mathrm{~cm}$ of sediment and gradually decreased in the deeper layers. At the impacted site, very few meiofaunal organisms were recorded at the deepest layers $(10-15,15-20 \mathrm{~cm})$, while at the same time, meiofaunal densities were remarkably higher at the non-impacted site (e.g., November 2009, May 2010). Likewise, a closer inspection of the meiofaunal community distribution revealed that the vertical pattern was greatly dependent on the site and seasons as well (Table 4). The significant site-layer effect was due to the magnitude of the differences in total between-site densities, rather than a change in community composition. Pair-wise comparisons revealed significant differences in vertical distribution in all seasons between the sites, with the exception of spring (March 2009 and 2010) and October 2010 (for layers 5-20 cm) (Table 3, Fig. 7).

\section{Discussion}

A submarine groundwater discharge process is extremely difficult to evaluate because of the dispersive character, complexity, and range of the processes (e.g. hydrodynamics) and factors (e.g. topographic relief and sediment permeability) controlling the fluxes. Comparisons are also difficult to make because of the diversity of techniques that have been used in other studies. The effect of SGD is clearly a complex issue. Our research provides information on a newly discovered shallow groundwater seepage in the Baltic Sea, focusing on benthic biota, in the hope of stimulating further work on the topic. This study demonstrated a significant decrease in meiofaunal abundance immediately adjacent to a submarine groundwater discharge point compared to a site without seepage. Changes in meiofaunal abundances were accompanied by changes in the meiofaunal assemblage, both at the temporal (seasonal) and small spatial scales (vertical distribution).

Earlier studies in Puck Bay revealed groundwater seepage in shallow coastal areas from Tertiary and Quaternary aquifers

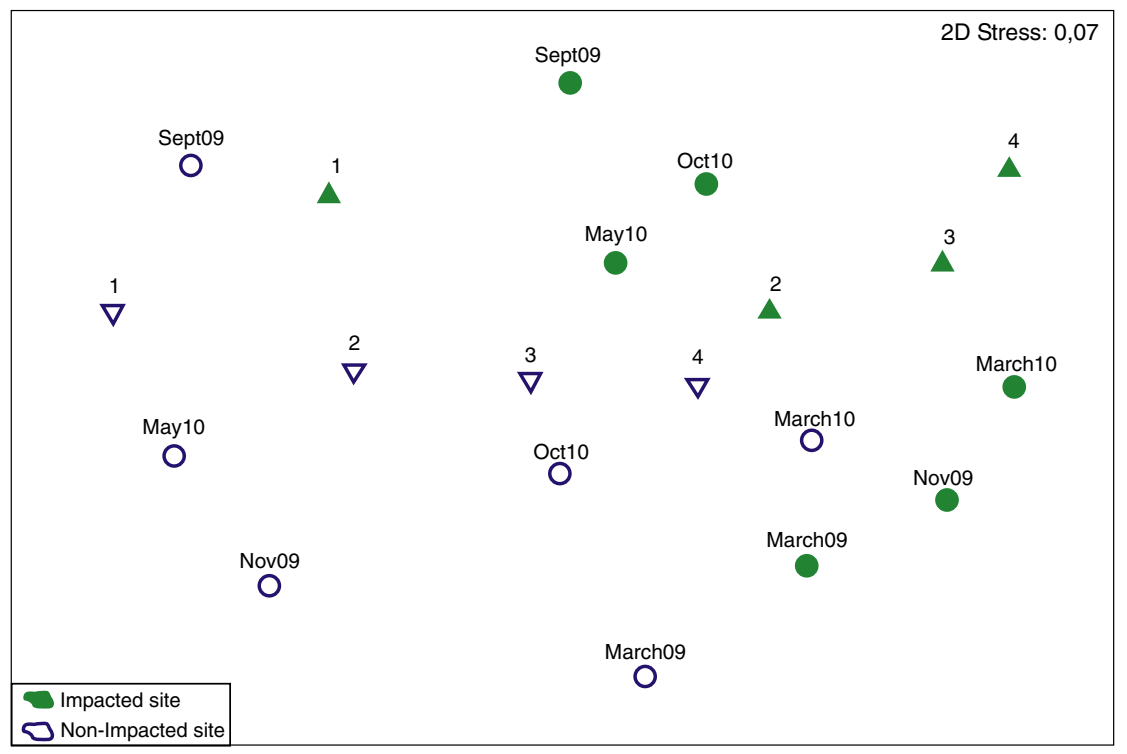

Fig. 5. MDS plot showing scale of variability between and inside selected factors based on averages for combined SixSe factor and SixLy factor. 
Table 3

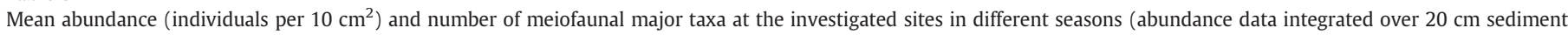
depth).

\begin{tabular}{|c|c|c|c|c|c|c|c|c|c|c|c|c|c|}
\hline & & \multicolumn{6}{|l|}{2009} & \multicolumn{6}{|l|}{2010} \\
\hline & & \multicolumn{2}{|l|}{ March } & \multicolumn{2}{|c|}{ September } & \multicolumn{2}{|c|}{ November } & \multicolumn{2}{|c|}{ March } & \multicolumn{2}{|l|}{ May } & \multicolumn{2}{|c|}{ October } \\
\hline & & I & $\mathrm{NI}$ & I & $\mathrm{NI}$ & I & $\mathrm{NI}$ & I & $\mathrm{NI}$ & I & $\mathrm{NI}$ & I & $\mathrm{NI}$ \\
\hline \multirow[t]{2}{*}{ Nematoda } & mean & 520.7 & 259.3 & 160.5 & 526.5 & 124.0 & 1470.6 & 68.5 & 80.8 & 94.0 & 827.6 & 78.7 & 638.2 \\
\hline & SD & 555.5 & 89.5 & 108.5 & 170.9 & 45.2 & 397.0 & 33.2 & 62.1 & 49.0 & 140.0 & 29.5 & 874.3 \\
\hline \multirow[t]{2}{*}{ Harpacticoida } & mean & 20.7 & 77.7 & 7.3 & 25.5 & 2.0 & 106.6 & 2.7 & 15.5 & 17.0 & 100.8 & 14.3 & 50.0 \\
\hline & SD & 9.3 & 42.5 & 5.5 & 8.3 & 1.5 & 52.8 & 3.3 & 27.8 & 14.8 & 14.4 & 7.0 & 39.0 \\
\hline \multirow[t]{2}{*}{ Turbellaria } & mean & 1.7 & 0.0 & 121.7 & 213.0 & 3.8 & 21.8 & 0.8 & 2.8 & 17.6 & 42.4 & 19.8 & 10.3 \\
\hline & SD & 2.9 & 0.0 & 73.5 & 42.3 & 2.6 & 2.9 & 2.0 & 3.0 & 10.8 & 3.4 & 9.0 & 13.6 \\
\hline \multirow{2}{*}{ Gastrotricha } & mean & 10.0 & 2.3 & 16.7 & 93.3 & 3.7 & 90.6 & 0.2 & 0.8 & 22.0 & 246.4 & 2.5 & 9.5 \\
\hline & SD & 9.5 & 2.5 & 20.9 & 49.2 & 3.4 & 94.7 & 0.4 & 1.6 & 43.1 & 107.0 & 2.1 & 7.1 \\
\hline \multirow[t]{2}{*}{ Rotifera } & mean & 0.0 & 0.0 & 426.5 & 621.0 & 0.0 & 0.0 & 0.0 & 0.0 & 0.8 & 3.8 & 2.8 & 0.8 \\
\hline & SD & 0.0 & 0.0 & 270.1 & 386.6 & 0.0 & 0.0 & 0.0 & 0.0 & 1.3 & 4.8 & 3.9 & 0.8 \\
\hline \multirow[t]{2}{*}{ Oligochaeta } & mean & 6.0 & 1.7 & 3.0 & 3.8 & 1.7 & 45.6 & 5.8 & 9.8 & 3.2 & 11.4 & 7.7 & 14.0 \\
\hline & SD & 5.6 & 0.6 & 1.8 & 1.9 & 1.9 & 36.3 & 5.4 & 8.1 & 2.3 & 8.0 & 5.0 & 26.1 \\
\hline \multirow[t]{2}{*}{ Polychaeta } & mean & 0.0 & 0.0 & 0.0 & 0.0 & 0.0 & 0.0 & 0.5 & 0.0 & 0.0 & 0.8 & 0.0 & 0.0 \\
\hline & SD & 0.0 & 0.0 & 0.0 & 0.0 & 0.0 & 0.0 & 0.8 & 0.0 & 0.0 & 0.8 & 0.0 & 0.0 \\
\hline \multirow[t]{2}{*}{ Ostracoda } & mean & 0.0 & 1.0 & 0.3 & 0.3 & 0.0 & 0.0 & 0.0 & 0.0 & 0.0 & 0.0 & 0.2 & 0.0 \\
\hline & SD & 0.0 & 1.0 & 0.5 & 0.8 & 0.0 & 0.0 & 0.0 & 0.0 & 0.0 & 0.0 & 0.4 & 0.0 \\
\hline \multirow[t]{2}{*}{ Tardigrada } & mean & 0.0 & 0.0 & 0.0 & 0.0 & 0.0 & 0.2 & 0.0 & 0.0 & 0.0 & 0.0 & 0.0 & 0.0 \\
\hline & SD & 0.0 & 0.0 & 0.0 & 0.0 & 0.0 & 0.4 & 0.0 & 0.0 & 0.0 & 0.0 & 0.0 & 0.0 \\
\hline \multirow[t]{2}{*}{ Acari } & mean & 1.0 & 1.3 & 0.5 & 0.7 & 0.0 & 0.2 & 0.7 & 0.2 & 1.4 & 13.8 & 2.3 & 1.0 \\
\hline & $\mathrm{SD}$ & 1.0 & 0.6 & 0.8 & 0.8 & 0.0 & 0.4 & 1.0 & 0.4 & 1.1 & 11.3 & 1.8 & 0.9 \\
\hline \multirow[t]{2}{*}{ Bivalvia } & mean & 0.0 & 0.0 & 2.8 & 1.3 & 0.0 & 0.2 & 3.2 & 1.0 & 0.4 & 0.8 & 2.2 & 0.0 \\
\hline & SD & 0.0 & 0.0 & 1.2 & 1.5 & 0.0 & 0.4 & 5.0 & 1.3 & 0.9 & 1.3 & 2.3 & 0.0 \\
\hline \multirow[t]{2}{*}{ Gastropoda } & mean & 0.0 & 0.0 & 1.0 & 0.5 & 0.2 & 0.0 & 0.0 & 0.0 & 0.0 & 0.2 & 0.0 & 0.0 \\
\hline & $\mathrm{SD}$ & 0.0 & 0.0 & 2.0 & 0.5 & 0.4 & 0.0 & 0.0 & 0.0 & 0.0 & 0.4 & 0.0 & 0.0 \\
\hline \multirow[t]{2}{*}{ Nauplii cop } & mean & 1.0 & 1.3 & 10.8 & 24.8 & 0.8 & 13.0 & 0.3 & 0.8 & 3.2 & 54.2 & 2.0 & 1.5 \\
\hline & SD & 1.0 & 1.5 & 5.3 & 4.8 & 1.3 & 8.0 & 0.5 & 2.0 & 4.3 & 33.0 & 2.3 & 2.1 \\
\hline \multirow[t]{2}{*}{ Nauplii cirr } & mean & 0.0 & 0.0 & 0.0 & 0.0 & 0.2 & 0.0 & 0.0 & 0.0 & 0.0 & 0.0 & 0.0 & 0.2 \\
\hline & $\mathrm{SD}$ & 0.0 & 0.0 & 0.0 & 0.0 & 0.4 & 0.0 & 0.0 & 0.0 & 0.0 & 0.0 & 0.0 & 0.4 \\
\hline TOTAL & & 561.0 & 344.7 & 751.2 & 1510.8 & 136.3 & 1748.8 & 82.7 & 111.8 & 159.6 & 1302.2 & 132.5 & 725.5 \\
\hline No of taxa & & 7 & 7 & 11 & 11 & 8 & 7 & 9 & 8 & 9 & 11 & 10 & 9 \\
\hline
\end{tabular}

I - impacted site, NI - non-impacted site.

(Piekarek-Jankowska, 1996) and in the deeper part of the Gulf of Gdansk (approximately $100 \mathrm{~m}$ depth) from Cretaceous water-bearing horizons (Falkowska, 1998; Falkowska and Piekarek-Jankowska, 1999). However, previous studies have not presented a measured flow rate of the freshwater discharge, instead only reporting hydrochemical effects

\section{Table 4}

Results from multivariate PERMANOVA analyses for differences in meiofaunal community structure between sites $(\mathrm{Si})$, seasons $(\mathrm{Se})$, sediment depths $(\mathrm{La})$, cores (Co), and interaction terms (A) and results from pair-wise comparisons for the factor season within investigated sites (B).

\begin{tabular}{|c|c|c|c|c|}
\hline \multicolumn{5}{|l|}{ A) } \\
\hline Source & $\mathrm{df}$ & MS & Pseudo-F & $\mathrm{P}($ perm $)$ \\
\hline $\mathrm{Si}$ & 1 & 33031 & 29.587 & 0.001 \\
\hline $\mathrm{Se}$ & 5 & 15349 & 13.740 & 0.001 \\
\hline La & 3 & 30482 & 53.885 & 0.001 \\
\hline SixSe & 5 & 6310.8 & 5.654 & 0.001 \\
\hline SixLa & 3 & 5890.6 & 10.414 & 0.001 \\
\hline SexLa & 15 & 2518.9 & 4.452 & 0.001 \\
\hline $\mathrm{Co}(\mathrm{SixSe})$ & 51 & 1103.4 & 1.960 & 0.001 \\
\hline SixSexLa & 15 & 1341 & 2.382 & 0.001 \\
\hline Res & 147 & 562.9 & & \\
\hline Total & 245 & & & \\
\hline \multicolumn{5}{|l|}{ B) } \\
\hline Site & & Season & $\mathrm{t}$ & $P($ perm $)$ \\
\hline \multirow{6}{*}{\multicolumn{2}{|c|}{ Impacted vs non-impacted }} & March 2009 & 0.91 & 0.677 \\
\hline & & September 2009 & 5.17 & 0.002 \\
\hline & & November 2009 & 4.98 & 0.004 \\
\hline & & March 2010 & 1.17 & 0.276 \\
\hline & & May 2010 & 3.61 & 0.011 \\
\hline & & October 2010 & 1.35 & 0.041 \\
\hline
\end{tabular}

Bold values indicate significant differences at $\mathrm{p}<0.05$. or rough calculations. Estimates of submarine groundwater discharge depend strongly on the evaluation technique used (Moore, 2010).

The rates of groundwater seepage measured in Puck Bay using seepage-meters varied significantly across both space and time, from slightly over zero to more than $180 \mathrm{l} \mathrm{m}^{-2} \mathrm{~d}^{-1}$. By comparison, submarine groundwater fluxes along the eastern coast of the USA range between 5 and $10 \mathrm{~lm}^{-2} \mathrm{~d}^{-1}$ (Simmons, 1992), while those at the Aleutian subduction zone are more in line with our data, with an average of $240 \mathrm{l} \mathrm{m}^{-2} \mathrm{~d}^{-1}$ (Suess et al., 1998). Additional estimates of SGD and seepage flux on a global scale, though quite limited, were presented by Burnett et al. (2001) and Taniguchi et al. (2002). Despite the wide range of variability in SGD calculations (depending on techniques, sediment type, location, etc.), which can vary from $0.01 \%$ to $80 \%$ of the total river flow, the importance of SGD in the global water cycle is unquestioned because of the high ratio of SGD to surface runoff (e.g., Bokuniewicz, 1980; Gallagher et al., 1996; Schlüter et al., 2004). For the Polish coastline alone $(500 \mathrm{~km})$, the total value of groundwater discharge to the Baltic Sea was calculated to be approximately $1.45 \mathrm{~km}^{3} \mathrm{yr}^{-1}$ (Kryza and Kryza, 2006), while estimations of $4.4 \mathrm{~km}^{3} \mathrm{yr}^{-1}$ were reported by Peltonen (2002) for the whole Baltic Sea. Based on these calculations, the groundwater discharge to the Baltic Sea is approximately $1 \%$ of the total surface freshwater input from rivers.

Sand permeability is a key factor in sandy sedimentary processes. Sediment characteristics of the study area were influenced mainly by wind-induced waves, leading to significant changes in permeability between seasons. Moreover, the observed differences in permeability could be explained by the sediment grain size, as significant differences in sediment characteristics were found between the impacted and non-impacted sampling sites. Other factors also likely affected sediment permeability. Permeability usually results from a combination of factors such as the porosity of the sediment, the density and distribution of the 

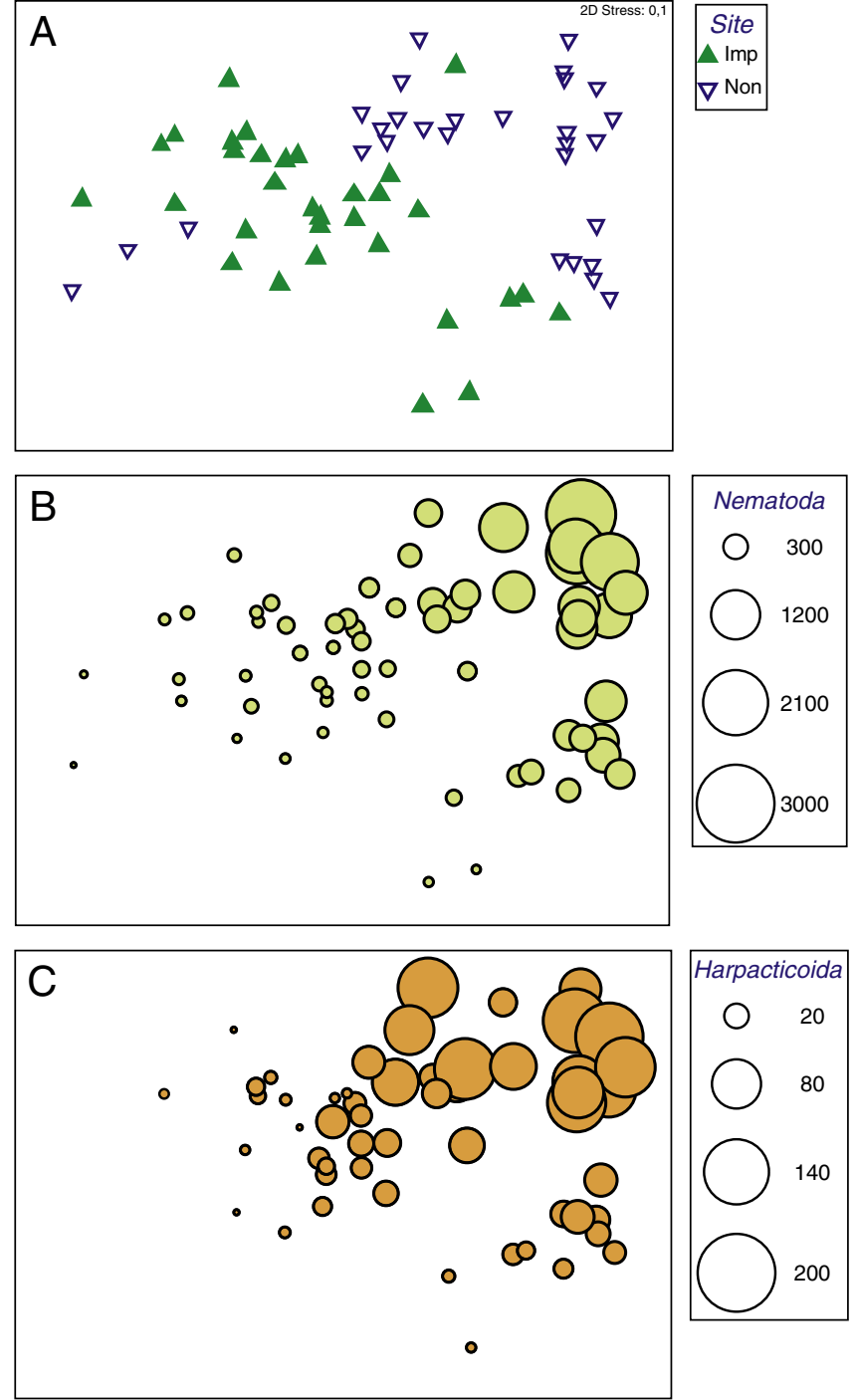

Fig. 6. MDS ordination from square-transformed meiofauna higher taxa at both sites: Non-impacted (Non) and Impacted (Imp) (A)' with bubbles representing nematodes (B) and harpacticoids (C) abundance. Bubble size equals relative nematodes and harpacticoids abundance at each sampling unit.

biota and the compounds extracted by living organisms, such as extrapolymeric substances. The amount of organic and inorganic fine particles in the sediment and even methane gas bubbles trapped between sand grains can affect permeability dynamics.

Although SGD may appear to be of minor importance in the global water cycle, it may have strong effects on the coastal zone ecosystem, at least at the local scale, because groundwater seepage is often an important pathway for diffuse pollution from the land. The chemical reactions leading to carbon, nutrient and metal release are important aspects of SGD (Moore, 2010). These reactions are usually mediated by bacteria or archaea occurring in aquifers and include ion desorption, carbonate dissolution, and the remineralisation of organic matter. In terms of nutrient discharge, the concentrations in the pore waters of the Puck Bay coastal zone vary greatly, depending on the season (Szymczycha et al., 2012), as follows: ammonium, 34-390 $\mu \mathrm{mol} /$; nitrate, $0.06-1.5 \mu \mathrm{mol} / \mathrm{l}$; nitrite, $0.19-0.28 \mu \mathrm{mol} / \mathrm{l}$; and phosphorus, 54.9-73.7 $\mu \mathrm{mol} / \mathrm{l}$. Szymczycha et al. (2012) also observed high concentrations of DIC up to $80 \mathrm{mg} \mathrm{C/l}$ in the pore water system at a site with direct groundwater seepage. Such high concentrations of these chemicals reduce fluid in the coastal zone and lead to hypoxia (Moore, 2010).

Creating a nutrient- and carbon-rich hypoxic environment results in less favourable conditions for organisms. The typical ecological impacted

total abundance [ind. $/ 10 \mathrm{~cm}^{2}$ ]

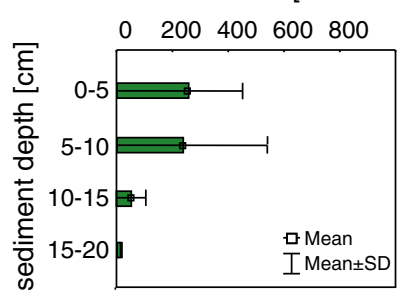

$0 \quad 40080012001600$

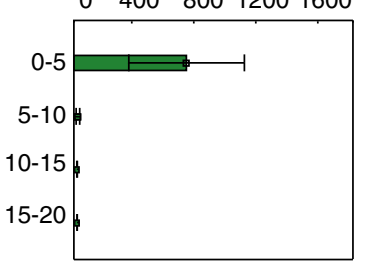

040080012001600
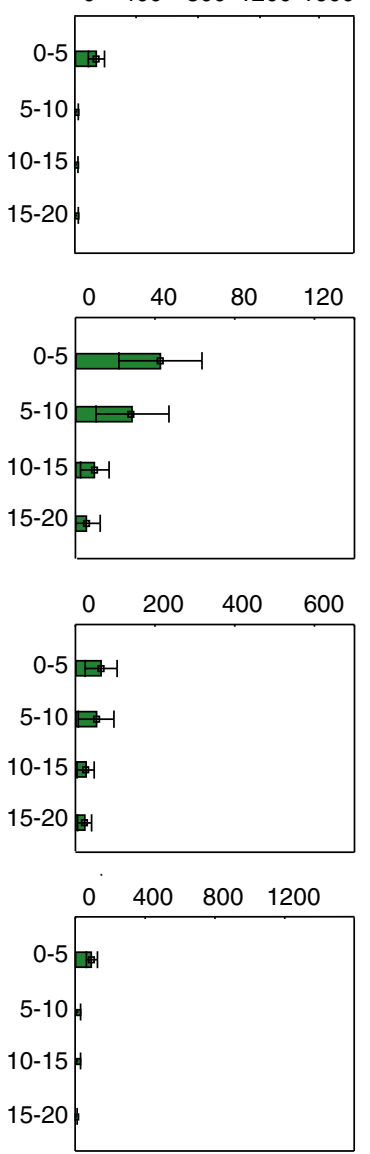

non-impacted

total abundance [ind. $/ 10 \mathrm{~cm}^{2}$ ]

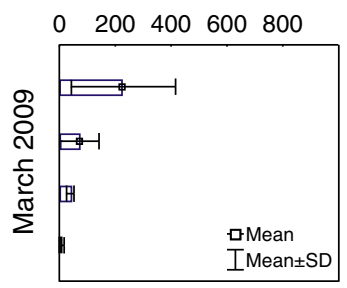

$0 \quad 40080012001600$

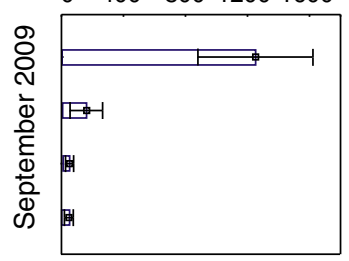

$0 \quad 40080012001600$
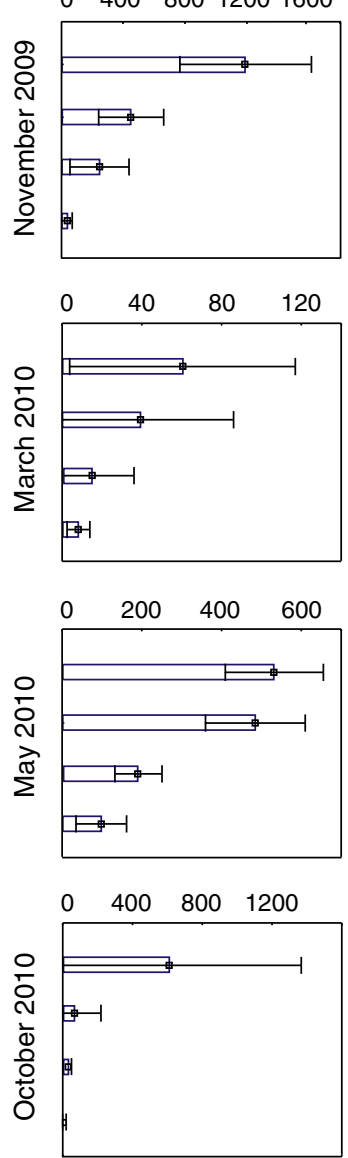

Fig. 7. Meiofaunal densities (mean and SD) in vertical sediment profile at both study sites during investigated seasons (different scales on $\mathrm{X}$ axes for different seasons).

consequences of hypoxic events are declines in the density and diversity of the benthos. High methane production may also cause anoxic conditions by replacing oxygen in sediments and can have severe (if species-selective) impacts on benthic communities. Such observations were also true for this study and were confirmed by the data. The best-fitted model (illustrated in Fig. 8), which explains almost $63 \%$ of the variability in the meiofaunal structure at the two sites, includes 5 statistically significant environmental variables (mean, skewness, salinity, $\mathrm{PO}_{4}^{3-}, \mathrm{NH}_{4}^{+}$) out of the 11 that were available. The 


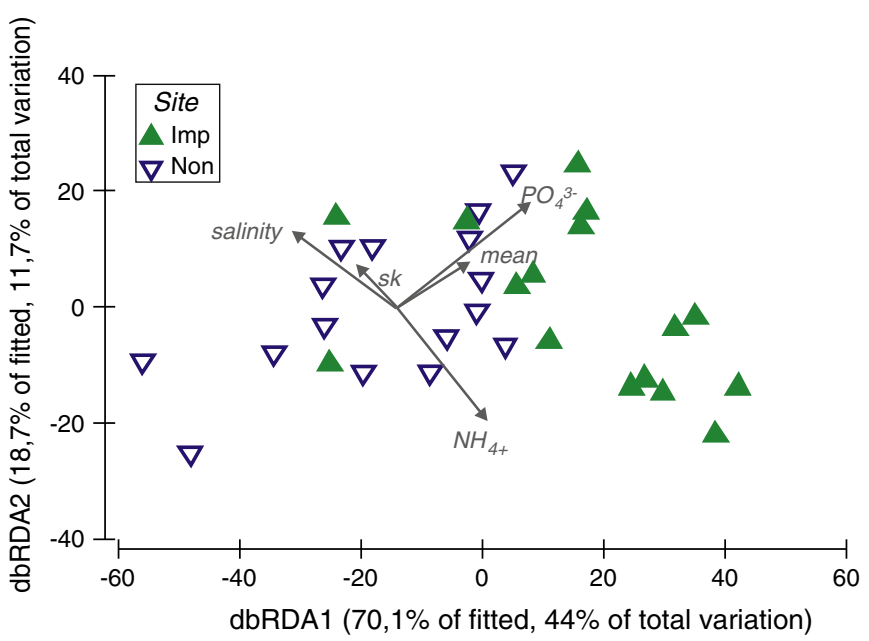

Fig. 8. Distance-based redundancy (dbRDA) plot illustrating the DISTLM model based on meiofauna assemblage data* and fitted environmental variables. Vectors length and direction corresponds to the correlation values. Mean: mean grain size, sk: skewness, salinity: salinity of groundwater, $\mathrm{PO}_{4}^{3-}$ : groundwater orthophosphate concentrations, $\mathrm{NH}_{4}^{+}$: groundwater ammonium concentrations. *Data for four seasons due to the lack of environmental data for March 2009 and October 2010.

concentrations of orthophosphate and ammonium explained nearly $50 \%$ of the variation in assemblage, and their higher concentrations at the impacted site negatively influenced the meiofauna community. In addition to the chemical characteristics of the pore waters, the salinity and sediment characteristics appeared to be major factors influencing the distribution pattern of the meiobenthos in the area of groundwater discharge. The mechanism of the meiofaunal response to submarine groundwater discharge might therefore be trophic and/or physiological. The trophic response is rather indirect and is related to potential food items, which might be negatively affected by nutrients carried by submarine waters. The physiological response is associated with the capacity for salinity regulation and tolerance to the salinity ranges of particular taxa (e.g., nematodes; Forster, 1998). In comparison to larger macrofaunal organisms, meiofauna are more resistant and usually more numerous in disturbed environments where macrofauna might already be absent (e.g., Giere, 2009; Kennedy and Jacoby, 1999; Warwick et al., 1990). Moreover, meiofauna with direct benthic development and generation times as short as one month are indicative of effects over smaller spatial and shorter temporal scales (Kennedy and Jacoby, 1999). The density of meiofaunal organisms in the groundwater seepage area was half that at the control site. This finding indicates that the impact of groundwater discharge is indeed severe, as the resilience of the meiofauna to environmental disturbance is relatively strong.

The impact of changes in salinity on marine ecosystems and their associated biotas can take various forms. Variations in the abundance and structure of meiobenthic assemblages were previously observed along salinity gradients in estuaries (Adão et al., 2009; Nozais et al., 2005) and areas influenced by freshwater run-off (Montagna et al., 2002) or brine disposal (Riera et al., 2011). Meiofaunal assemblages have also been used to monitor the impacts of pollution in coastal marine environments (Fraschetti et al., 2006; Mazzola et al., 2000; Warwick et al., 1990). The general outcome from these studies is that such disturbances alter meiofaunal community characteristics (abundance, diversity, biomass, composition), but the direction of the changes is not always clear.

The univariate and multivariate analyses used in our study revealed significant responses of the meiofauna to submarine groundwater discharge. The disturbance caused by SGD affected the number of individuals in meiofaunal communities and produced significant reductions of meiofaunal densities in the impacted samples. Nematodes and harpacticoids - two of the most abundant taxa in the meiobenthos - were present at significantly lower densities at the impacted site. The clear separation of meiobenthos assemblages between the sites is mainly due to the gradual increase in their abundance from the impacted to the non-impacted site. Other taxa that seemed to be affected by SGD disturbance were oligochaetes and gastrotrichs. Differences in community structure between the impacted and non-impacted sites were observed throughout the study period, with the exception of late winter/ early spring (March 2009 and 2010). At the same time, the SGD did not cause changes in the number of recorded taxa because their richness was highly comparable between sites throughout the study. The collection of samples in different seasons reduces the likelihood of under- or overestimation of SGD impacts associated with natural seasonal fluctuations in meiofaunal abundance.

The negative ecological effects of groundwater seepage were also confirmed by the vertical distribution of the meiofauna. Meiofaunal organisms were rare in the sediment from the seepage area in the layers below a depth of $10 \mathrm{~cm}$, whereas considerably higher meiofaunal densities were noted at the control site, even in the deepest sediment layers (e.g., May 2010). The deepest layers at the impacted site were characterised by high concentrations of ammonium and orthophosphate (Szymczycha et al., 2012). From the increasing mean grain size through the sediment layers and higher permeability values in the sediments from the seepage area, we can conclude that the meiofauna are significantly impoverished by SGD. Thus, we postulate that submarine groundwater discharge plays an important role in the shallow coastal zone of Puck Bay and has a negative impact on the density and vertical zonation of the meiofauna.

The groundwater discharge phenomenon should be considered in future ecological studies. This phenomenon can affect the abundance, spatial and vertical distribution, and taxonomic composition of benthic communities, including both macro- and meiofauna. It is not yet the standard practice for benthic studies to include the potential negative impact of groundwater and the consequences of its changes to chemical parameters, which occur patchily and locally.

\section{Conclusions}

The coastal shallow zone of Puck Bay is an area of important submarine groundwater discharge to the Baltic Sea. The discharge is a significant source of nutrients and carbon release to coastal waters. Due to the increased input of organic compounds, low oxygen concentrations or even hypoxic conditions might be observed in the sediment. Therefore, methanogenesis, one of the terminal anaerobic decomposition processes, occurs, leading to the high production and emission of methane. This phenomenon affects the spatial distribution, abundance and taxonomic composition of benthic communities and results in a significant reduction in meiofaunal density. A patchy distribution of interstitial fauna on a local scale reflects the environmental conditions of the particular site. The results and observations from the seepage area of Puck Bay may be representative of other coastal zones of the Baltic Sea where SGD from different aquifers could have similar relevance.

\section{Acknowledgements}

We thank the numerous colleagues involved in the project, both intellectually and in the field work. We are much indebted to K. R. Clarke for his comments on the statistical analyses. This work was funded by the AMBER project, which is part of the Joint Baltic Sea Research Programme and the development programme BONUS + (BMBF Project No. 03F0485A).

\section{References}

Adão, H., Alves, A.S., Paticio, J., Neto, J.M., Costa, M.J., Marques, J.C., 2009. Spatial distribution of subtidal Nematoda communities along salinity gradient in southern European estuaries. Acta Oecologica 35, 287-3000. 
Anderson, M.J., Gorley, R.N., Clarke, K.R., 2008. PERMANOVA for PRIMER: Guide to Software and Statistical Methods. PRIMER-E Ltd., Plymouth, United Kingdom (214 pp.).

Austen, M.C., McEvoy, A.J., Warwick, R.M., 1994. The specificity of meiobenthic community response to different pollutants: results from microcosm experiments. Mar. Pollut. Bull. 28, 557-563.

Beck, A.J., Rapaglia, J.P., Cochran, J.K., Bokuniewicz, H.J., Yang, S., 2008. Submarine groundwater discharge to Great South Bay, NY, estimated using Ra isotopes. Mar Chem. 109, 279-291.

Bell, R.J., Short, R.T., Van Amerom, F.H.W., Byrne, R.H., 2007. Calibration of an in situ membrane inlet mass spectrometer for measurements of dissolved gases and volatile organics in seawater. Environ. Sci. Technol. 41, 8123-8128.

Bell, R.J., Short, R.T., Byrne, R.H., 2011. In situ determination of total dissolved inorganic carbon by underwater membrane introduction mass spectrometry. Limnol. Oceanogr. Methods 9, 164-175.

Blott, S.J., Pye, K., 2001. Gradistat: a grain size distribution and statistics package for the analysis of unconsolidated sediments. Earth Surf. Process. Landforms 26, 1237-1248.

Bokuniewicz, H., 1980. Groundwater seepage into Great South Bay, New York. Estuar. Coast. Mar. Sci. 10, 437-444.

Burnett, W.C., Taniguchi, M., Oberdorfer, J., 2001. Measurement and significance of the direct discharge of groundwater into the coastal zone. J. Sea Res. 46, 109-116.

Burnett, W.C., Bokuniewicz, H., Huettel, M., Moore, W.S., Taniguchi, M., 2003. Groundwater and pore water inputs into the coastal zone. Biogeochemistry 66, 3-33.

Burnett, W.C., Aggarwal, P.K., Aureli, A., Bokuniewicz, H., Cable, J.E., Charette, M.A., Kontar, E., Krupa, S., Kulkarni, K.M., Loveless, A., Moore, W.S., Oberdorfer, J.A., Oliveira, J., Ozyurt, N., Povinec, P., Privitera, A.M.G., Rajar, R., Ramessur, R.T., Scholten, J., Stieglitz, T., Taniguchi, M., Turner, J.V., 2006. Quantifying submarine groundwater discharge in the coastal zone via multiple methods. Sci. Total. Environ. 367, 498-543.

Bussmann, I., Dando, P.R., Niven, S.J., Suess, E., 1999. Groundwater seepage in the marine environment: role for mass flux and bacterial activity. Mar. Ecol. Prog. Ser. 178, 169-177.

Corbett, D.R., Dillon, K., Burnett, W., Schaefer, G., 2002. The spatial variability of nitrogen and phosphorus concentration in a sand aquifer influenced by onsite sewage treatment and disposal systems: a case study on St. George Island, Florida. Environ. Pollut. 117, 337-345.

Costa Jr., O.S., Attrill, M.J., Nimmo, M., 2006. Seasonal and spatial controls on the delivery of excess nutrients to nearshore and offshore coral reefs of Brazil. J. Mar. Syst. 60, 63-74.

Falkowska, L., 1998. Anomalies in the physical and chemical structure of the Gdansk Deep caused by groundwater seepage. Oceanologia 40 (2), 1-12.

Falkowska, L., Piekarek-Jankowska, H., 1999. Submarine seepage of fresh groundwater: disturbance in hydrological and chemical structure of the water column in the Gdańsk Basin. ICES J. Mar. Sci. 56, 153-160.

Falkowska, L., Burska, D., Bolalek, J., Roguszczak, D., 1998. Short-term changes in hydrochemical constituents in the water column of the Gdańsk Deep in spring season (Baltic Sea). Part. 1 nutrient and oxygen concentration in relation to the density stratification. Oceanologia 40 (2), 87-112.

Folk, R.L., Ward, W.C., 1957. Brazos River bar [Texas]: a study in the significance of grain size parameters. J. Sediment. Petrol. 27, 3-26.

Forster, S.J., 1998. Osmotic stress tolerance and osmoregulation of intertidal and subtidal nematodes. J. Exp. Mar. Biol. Ecol. 2241, 109-125.

Fraschetti, S., Gambi, C., Giangrande, A., Musco, L., Terlizzi, A., Danovaro, R., 2006. Struc tural and functional response of meiofauna rocky assemblages to sewage pollution. Mar. Pollut. Bull. 52, 540-548.

Gallagher, D.L., Dietrich, A.M., Reay, W.G., Hayes, M.C., Simmons, G.M., 1996. Ground water discharge of agricultural pesticides and nutrients to estuarine surface water. Ground Water Monit. Rev. 16, 118-129.

Gazeau, F., Smith, S.V., Gentill, B., Frankignoulle, M., Gattuso, J.-P., 2004. The European coastal zone: characterization and first assessment of ecosystem metabolism. Estuarine Coastal Shelf Sci. 60, 673-694

Gentz, T., Schlüter, M., 2012. Underwater cryotrap-membrane inlet system (CT-MIS for improved in situ analysis of gases. Limnol. Oceanogr. Methods 10, 317-328.

Giere, O., 2009. Meiobenthology. The Microscopic Motile Fauna of Aquatic Sediments, 2nd revised and extended edition. Springer-Verlag, Berlin Heidelberg (527 pp.).

Jankowska, H., Matciak, M., Nowacki, J., 1994. Salinity variations as an effect of groundwater seepage through the seabed (Puck Bay, Poland). Oceanologia 36 (1), 33-46.

Jeong, J., Kim, G., Han, S., 2012. Influence of trace element flux from submarine groundwater discharge (SGD) on their inventories in coastal waters off volcanic island, Jeju, Korea. Appl. Geochem. 27 (1), 37-43.

Kampbell, D.H., Wilson, J.T., Vandegrift, S.A., 1989. Dissolved-oxygen and methane in wate by a Gc headspace equilibration technique. Int. J. Environ. Anal. Chem. 36, 249-257.

Kennedy, A.D., Jacoby, C.A., 1999. Biological indicators of marine environmental health: meiofauna-a neglected benthic component? Environ. Monit. Assess. 54, 47-68.

Kim, G., Ryu, J., Yang, H., Yun, S., 2005. Submarine groundwater discharge (SGD) into the Yellow Sea revealed by Ra and Ra isotopes: implication for global silicate fluxes. Earth Planet. Sci. Lett. 237, 156-166.

Klute, A., Dirksen, C., 1986. Hydraulic conductivity and diffusivity: laboratory methods. In: Klute, A. (Ed.), Methods of Soil Analysis - Part 1 - Physical and Mineralogical Methods. American Society of Agronomy, pp. 687-700.

Kohout, F.A., 1964. The flow of fresh water and salt water in the Biscayne Bay aquifer of the Miami area, Florida. In: Seawater in coastal aquifer. U.S. Geol. Surv. Water Supply Pap. 161, 12-32.

Kryza, J., Kryza, H., 2006. The analytic and model estimation of the direct groundwater flow to the Baltic Sea on the territory of Poland. Geologos 10,153-165.

Lapointe, B.E., O'Connell, J.D., Garrett, G.S., 1990. Nutrient couplings between on-site sewage disposal systems, groundwaters, and nearshore surface waters of the waters of the Florida Keys. Biogeochemistry 10, 289-307.
Lee, D.R., 1977. A device for measuring seepage flux in lakes and estuaries. Limnol. Oceanogr. 22, 140-147.

Lysiak-Pastuszak, E., 2000. An assessment of nutrient conditions in the Southern Baltic Sea between 1994 and 1998. Oceanologia 42 (4), 425-448.

Mazzola, A., Mirto, S., La Rosa, T., Fabiano, M., Danovaro, R., 2000. Fish-farming effects on benthic community structure in coastal sediments: Analysis of meiofaunal recovery. ICES J. Mar. Sci. 57, 1454-1461.

McLachlan, A., Brown, A.C., 2006. The Ecology of Sandy Shores, second edition. Academic Press, United States of America (373 pp.).

Miller, D.C., Ullman, W.J., 2004. Ecological consequences of groundwater discharge to Delaware Bay, United States. Ground Water 42, 959-970.

Montagna, P.A., Kalke, R.D., Ritter, C., 2002. Effect of restored freshwater inflow on macrofauna and meiofauna in upper Rincon Bayou, Texas, USA. Estuaries 25, $1436-1447$.

Moore, W.S., 1999. The subterranean estuary: a reaction zone of ground water and sea water. Mar. Chem. 65, 111-125.

Moore, W.S., 2010. The effect of submarine groundwater discharge on the ocean. Annu. Rev. Mar. Sci. 2, 59-88.

Nixon, S.W., Oviatt, C.A., Frithsen, J., Sullivan, B., 1986. Nutrients and the productivity of estuarine and coastal marine ecosystems. J. Limnol. Soc. S. Afr. 12, 43-71.

Nozais, C., Perissinotto, R., Tita, G., 2005. Seasonal dynamics of meiofauna in a South African temporarily open/closed estuary (Mdloti Estuary, Indian Ocean). Estuarine Coastal Shelf Sci. 62, 325-338

Opaliński, K.W., Maciejewska, K., Urban-Malinga, B., Węsławski, J.M., 2010. The oxygen fluxes of sandy littoral areas: quantifying primary and secondary producers in the Baltic Sea. Mar. Pollut. Bull. 61, 211-214.

Peltonen, K., 2002. Direct groundwater flow to the Baltic Sea. Nordic council of Ministers, Copenhagen (145 pp.).

Pempkowiak, J., Szymczycha, B., Kotwicki, L., 2010. Submarine groundwater discharge (SGD) to the Baltic Sea. Rocz. Ochr. Śr. 12, 17-32.

Pfannkuche, O., Thiel, H., 1988. Sample processing. In: Higgins, R.P., Thiel, H. (Eds.), Introduction to the Study of Meiofauna. Smithsonian Institution Press, Washington D.C., pp. 134-145 (London).

Piekarek-Jankowska, H., 1996. Hydrochemical effects of submarine groundwater discharge to the Puck Bay. Geogr. Pol. 67, 103-119.

Piekarek-Jankowska, H., 1994. Zatoka Pucka jako obszar drenażu wód podziemnych, Wyd. UG. 104 (in Polish)

Rapaglia, J., Koukoulas, S., Zaggia, L., Lichter, M., Manfe, G., Vafeidis, A.T., 2012. Quantification of submarine groundwater discharge and optimal radium sampling distribution in the Lesina Lagoon, Italy. J. Mar. Syst. 91, 11-19.

Riera, R., Tuya, F., Sacramentto, A., Ramos, E., Rodiguez, M., Monterroso, Ó., 2011. The effect of brine disposal on a subtidal meiofauna community. Estuarine Coastal Shelf Sci. 93, 359-365.

Schlüter, M., Gentz, T., 2008. Application of membrane inlet mass spectrometry for online and in situ analysis of methane in aquatic environments. J. Am. Soc. Mass Spectrom. 19, 1395-1402.

Schlüter, M., Sauter, E.J., Andersen, C.E., Dahlgaard, H., Dando, P.R., 2004. Spatial distribution and budget for submarine groundwater discharge in Eckernförde Bay (Western Baltic Sea). Limnol. Oceanogr. 49, 157-167.

Schoeneich, K., 1965. The origin of the Polish Baltic seashore. Prz. Geol. 5, 196-198.

Schratzberger, M., Jennings, S., 2002. Impacts of chronic trawling disturbance on meiofaunal communities. Mar. Biol. 141, 991-1000.

Schratzberger, M., Warwick, R.M., 1999. Differential effects of various types of disturbances on the structure of nematode assemblages: an experimental approach. Mar. Ecol. Prog. Ser. 181, 227-236.

Short, R.T., Fires, D.P., Kerr, M.L., Lembke, C.E., Toler, S.K., Wenner, P.G., Byrne, R.H., 2001. Underwater mass spectrometers for in situ chemical analysis of the hydrosphere. J. Am. Soc. Mass Spectrom. 12, 676-682.

Short, R.T., Fries, D.P., Toler, S.K., Lembke, C.E., Byrne, R.H., 2006. Development of an underwater mass spectrometry system for in-situ chemical analysis. Meas. Sci. Technol. 10, 1195-1201.

Simmons, G.M., 1992. Importance of submarine groundwater discharge (SGWD) and seawater cycling to material flux across sediment/water interfaces in marine environments. Mar. Ecol. Prog. Ser. 84, 173-184.

Suess, E., Bohrmann, G., von Huene, R., Linke, P., Wallmann, K., Lammers, S., Sahlig, H., Winckler, G., Lutz, R.A., Orange, D., 1998. Fluid venting in the Aleutian subduction zone. J. Geophys. Res. 103, 2597-2614.

Szymczycha, B., Vogler, S., Pempkowiak, J., 2012. Nutrient fluxes via submarine groundwater discharge to the Bay of Puck, southern Baltic Sea. Sci. Total. Environ. http://dx.doi.org/10.1016/j.scitotenv.2012.08.058.

Taniguchi, M., Burnett, W.C., Cable, J.E., Turner, J.V., 2002. Investigation of submarine groundwater discharge. Hydrol. Processes 16, 2115-2129.

Valiela, I., Costa, J., Foreman, K., Teal, J.M., Howes, B., Aubrey, D., 1990. Transport of groundwater-borne nutrients from watersheds and their effects on coastal waters. Biogeochemistry 10, 177-197.

Warwick, R.M., Platt, H.M., Clarke, K.R., Agard, J., Gobin, J., 1990. Analysis of macrobenthic and meiobenthic community structure in relation to pollution and disturbance in Hamilton Harbour, Bermuda. J. Exp. Mar. Biol. Ecol. 138, 119-142.

Wenner, P.G., Bell, R.J., van Amerom, F.H.W., Toler, S.K., Edkins, J.E., Hall, M.L., Koehn, K., Short, R.T., 2004. Environmental chemical mapping using an underwater mass spectrometer. Trac Trends Anal. Chem. 23, 288-295.

Windom, H.L., Moore, W.S., Felipe, L., Niencheski, H., Jahnke, R.A., 2006. Submarine groundwater discharge: a large, previously unrecognized source of dissolved iron into the southern Atlantic Ocean. Mar. Chem. 102, 252-266. 